\title{
THE FOUNDATION YEARS OF THE ROYAL SOCIETY OF TASMANIA, 1843-86
}

\author{
by Gillian Winter
}

(with three plates)

being the text of a talk delivered at the Annual General Meeting of the Society in its Sesquicentenary Year.

Winter, G.A., 1993 (31:viii): The Foundation years of the Royal Society of Tasmania, 1843-86. Pap. Proc. R. Soc. Tasm. 127: 61-66. https://doi.org/10.26749/rstpp.127.61 ISSN 0080-4703. Tasmaniana Library, State Library of Tasmania, 91 Murray Street, Hobart, Tasmania, Australia 7000.

The early history of the Royal Society is of an organisation broadly based in its scientific activity: developing and administering the Colonial Gardens in Hobart; providing a forum for papers, both practical and scientific; publishing; building a library through the exchange of its publications; and establishing a museum through donations and exchange. Involving both local people and many international corresponding members, the Society was the means by which the scientific world could learn about Tasmania and the local community could learn about European scientific developments and also be informed about local environmental issues.

Key Words: Royal Society of Tasmania, scientific societies, scientific history.

\section{INTRODUCTION}

The Royal Society of Tasmania was the first Royal Society to be established outside the United Kingdom. Perhaps of even more interest than its age, however, is the evidence that its early activities were broader in scope than any other scientific body in Australia in the mid- and late-nineteenth century. ${ }^{1}$ [Notes will be found at the end of the paper.]

It was set up to administer the Colonial Gardens. After a modest beginning, it soon moved into a period of vigorous activity, branching out to establish a Museum and Library. To build up these three institutions, the Society contacted numerous international bodies and countless individuals, both at home and abroad, arranging for the exchange of items or soliciting donations.

Scientific societies were established in other colonies in the decades after the 1840 s, but they were slow to publish regular journals and build up their libraries through exchange. In no other colony were the botanical gardens under the control of a scientific society, and in Victoria and Queensland, where museums were established as adjuncts to scientific societies, control very soon passed to the University of Melbourne and the Queensland Government, respectively. Other Australian societies had international contacts, but Tasmania's contacts were more numerous because of its diverse activities. The Museum and Gardens also gave local residents a greater opportunity to participate more fully in the Society's work than other societies could provide. Tasmanian members could be donors if they could not deliver a paper. Many, indeed, considered the administration and development of the Gardens and Museum the chief activities of the Society.

The government grant, given to the Society from its inception, was designed to support the Museum and Gardens, but it was often insufficient for the adequate maintenance of the collections and left nothing for enlarging them. This was done chiefly by donation and exchange. The Society carefully husbanded its resources and applied judicious pressure to gain financial, and other, help for its growing collections. At times it suffered from severe financial difficulties and its very existence depended on the initiative, energy and perseverance of a few members.
At first, members of the Society enjoyed a number of special privileges relating to the Gardens and Museum but these were gradually revoked and the Society increasingly saw itself as the trustee and administrator of two public institutions. (Even the Library was, in the beginning, planned as the nucleus of a public library.) It is hardly surprising, then, that in 1885 the Society arranged to have the Museum and Gardens incorporated and permanently endowed as public bodies.

The Fellows of the Society met regularly to read and discuss scientific papers which were published and had a worldwide circulation. Contributions were drawn from all over Australia and even overseas, as the Society had a number of active Corresponding Members. A lot of original material, particularly relating to Australia's flora, fauna and geology, was first brought forward at meetings of the Society. Many other papers were intended to increase colonists' knowledge of their new country in the hope that this information could be turned to profitable advantage. This emphasis on the "practical" aspects of science is understandable.

The Society was "exclusive" in the sense that it was started under, and continued to enjoy, vice-regal patronage and many of its members were high-ranking civil servants, wealthy graziers, or clergymen. Its membership, however, could not be compared with that of European societies, which were largely composed of scientists. Without even a university to provide a trained nucleus of scientists, the Royal Society depended on amateurs (some of whom were particularly gifted men) and a few scientifically trained men in government employment to keep it going. It was open to anyone who was interested in science, open in fact to anyone who cared to belong. For some it was an agreeable "club" to which many of their friends belonged, and which provided discussions which were both "educational" and enjoyable.

The years to 1863 were those of great activity, successful but presenting financial problems because the Society overcommitted its resources. The next twenty years were times of consolidation and solid achievement. An overall examination of the history of the first forty years of the Society clearly shows that it was the channel of communication through which the world could learn more 
about Tasmania's natural history and scientific endeavours. It was also the means by which people in the colonies were made aware of European scientific developments. But it also undertook a number of tasks which are now the responsibility of other bodies, usually government departments. They include: meteorology, industrial development, tourism, immigration, public health, agriculture, mapping and land surveying, fisheries, and scenery and wildlife preservation.

\section{PRECURSORS OF THE SOCIETY}

The foregoing introductory remarks on the foundation years of the Royal Society (1843-86) summarise the achievements and significance of these early years. The establishment and the operations of the Society during this period, particularly in relation to its three-fold responsibility (the Gardens; the Museum; the presentation and publication of scientific papers), deserve more detailed examination.

First, perhaps, some consideration of the men who enabled a Royal Society to be formed in Hobart Town, Van Diemen's Land in 1843. On the title page of the Minute Book for $1841^{2}$ of the immediate forerunner of the Royal Society, the Tasmanian Society, is a charming vignette of a platypus, captioned "all things are queer and opposite". It was this recognition by some settlers - that they were not only living in a century of unparalleled interest in scientific matters, but were living in a country that offered evidence of significant variations from the European natural world - which gave them a sense of responsibility to examine and record the antipodean environment. There were, too, the "practical" men of science who wished to pool their growing knowledge of the colony to promote agriculture and industry. There were others who saw science, like literature and art, as a unifying agent in the community, turning men's attentions from politics and the pursuit of wealth, which were seen as divisive. And, of course, there were the acclimatisers, who represent that curious amalgam of scientific curiosity, sentiment and greed which resulted in such ecological and economic disasters as the introduction of the rabbit - as well as such benefits as the salmon. All these men were, through the membership of successive scientific bodies in Hobart, part of a "scientific tradition", albeit a primitive one.

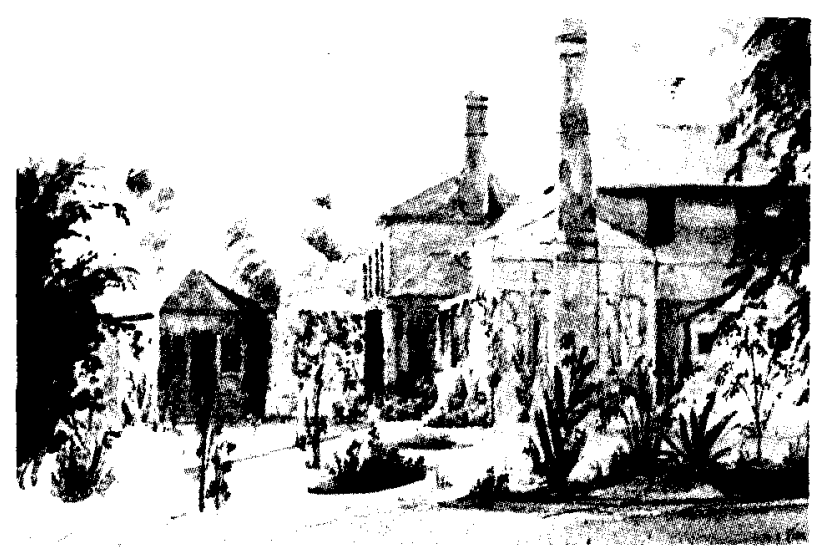

PLATE 1

Old Government House, Macquarie Street, Hobart, where the Society first met on 14 October 1843. Watercolour by Owen Stanley, 1840-41. (Royal Society Collection, held at the Tasmanian Museum and Art Gallery, Hobart.)
The Van Diemen's Land Agricultural Society, established mid-1821 under the presidency of Lieutenant-Governor Sorell, may have had as its main aims the combating of sheep stealing and the raising of the level of animal husbandry in the colony but it was the first "scientific" society in Australia.

Dr John Henderson founded the Van Diemen's Land Scientific Society in 1829, under the patronage of Lieutenant-Governor Arthur, modelling it upon the colonial medical and scientific societies he had encountered in India. He aimed to conduct local scientific experiments and send specimens to scientists in Europe, and he quickly gathered 100 members for his Society. But he soon quarrelled with John Burnett (his Society's Vice-Patron and the Colonial Secretary) and found it expedient to depart for New South Wales.

The third of the Royal Society's forerunners - the Tasmanian Society - was founded by Lieutenant-Governor Sir John Franklin, a Polar hero and a member of English scientific societies, who found that his English correspondents were keenly interested in information about the remote colony he was administering. He presided regularly at meetings (held at Government House), financed the publication of the Tasmanian Journal, and welcomed visiting scientists (who included the explorer Count Strzelecki; the ornithologist John Gould; the Antarctic explorers James Ross and Francis Crozier and their French counterpart Dumont d' Urville). As with education and the arts, Sir John and Lady Franklin were committed to stimulating local scientific endeavours to inform and uplift the intellectual and moral character of the community.

\section{ESTABLISHMENT OF THE SOCIETY}

Sir John Eardley-Wilmot, Franklin's successor, set up the Van Diemen's Land Horticultural and Botanical Society later the Royal Society - because he felt that he could not maintain the Colonial Gardens at his own expense but did not want to see them abandoned. The Society, which was to administer the Gardens, financed by a Government grant, was to operate under rules based on the Linnaean and Horticultural Society in England. The Governor sought Royal patronage for this new body. Eardley-Wilmot had accepted presidency of the Tasmanian Society but then appeared to decide that it should be the nucleus of his new Society. The 37 resident Tasmanian Society members were entitled to be among the first fifty foundation Fellows of the Society. But they objected to having to pay an entrance fee and all but five ( and many of the invited prospective new members) walked out of the initial meeting in October 1843. Eardley-Wilmot was left with 18 people for his new Society.

The Society's aim was "to develop the physical character of the Island and illustrate its natural history and production". ${ }^{3}$ Under the 1843 rules Fellows had access to the Gardens, Museum and Library and might take visitors to these places. Ladies were to be admitted as Fellows "upon the same terms, with the same privileges and under the same regulations in all respects as gentlemen". 4

Administratively, the period from 1843-48 may be seen as one where the Society's activities were concentrated on overseeing the management and development of the 14 acres (5.67 ha) of Gardens; refining the rules for the regulation of the Society; and reaching agreement with the rival Tasmanian Society. Her Majesty agreed to be the Society's patron and 
the Royal Society of Van Diemen's Land for Horticulture, Botany and the Advancement of Science was a reality from September 1844.

But its pre-eminent scientific status was not recognised by all local people. Botanist R.C. Gunn, one of the luminaries of this early period (the only Tasmanian in the nineteenth century to be made a Fellow of the English Royal Society), claimed in 1845: "The Royal Botanical Society of Van Diemen's Land will go to the devil"s and said of the Tasmanian Society now based in Launceston: "Science being republican, we have got rid of all vice-presidents, etc and flourish alike as humble members". ${ }^{6}$

Under pressure from Lieutenant-Governor Denison, however, the Royal Sociery made it easier from 1848 for members of the Tasmanian Society to join and, although no formal amalgamation took place, within eighteen months all active resident members had transferred to the Royal. Initially, the Society made little progress because it did not have a petmanent paid Secretary although, had the Government been willing to increase its grant in 1844, the young Joseph Hooker was willing to return to the colony and fulfil the role. But the $£ 300$ salary was not forthcoming. Instead, F.W. Newman, the new Superintendent of the Gardens, was appointed. Governor Eardley-Wilmot objected to a "practical botanist and gardener": He required someone of "superior education, and scientific and literary acquirements": 7 his was not a horticultural but a scientific society. He urged the Society to action, and it undertook to hold monthly meetings to read and discuss papers, although one only was read in 1846. A cottage at the gardens was set up as a Museum, reading and meeting room and donations of natural history specimens and books were sought from English scientific societies.

\section{WILLIAM DENISON'S CONTRIBUTION}

The spur to greater action, however, was the man who has been described as "the great resuscitator of scientific societies": Lieutenant-Governor Sir William Denison. He appointed Dr Joseph Milligan as secretary, ensuring that he had another civil post so that his salary from the Society need not be large. Milligan's reports on the coal fields of Tasmania - part of his government work - were read to the Society and became the first papers it published.

From the time Milligan became Secretary the Society began to function as a genuine scientific body and he was to remain active in the organisation for twelve years. Denison wrote to a friend: "I have succeeded in making a society, which had been nominally established several years, perform some work, and I hope to be able to forward home a specimen of its labours shortly."

Sorell, Arthur, Franklin and Eardley-Wilmot had all been associated with different scientific societies but Denison worked within the existing Society: he gave papers frequently and was a prolific donor and was justly lauded for his activity, generosity and enthusiasm.

It was Denison who was behind the Sociery's plan to send Tasmanian specimens to the Great Exhibition in London in 1851. It became a public undertaking but the Society acted as the recipient for specimens and arranged for a local exhibition before they were dispatched to England. Tasmania was said to have sent more exhibits, in proportion to its size and population, than any other British colony. Under the
Society's arrangements many of the specimens were given to the British Museum and the Linnaean Society after the Exhibition.

\section{ACTIVITIES OF THE SOCIETY}

In 1856 the Sociery sent products to the Paris Exhibition, a selection which was consciously chosen to appeal to potential immigrants. The Society also reprinted a pamphlet written by Denison for intending emigrants and distributed to public institutions in England lithographs of Hobart by artist Knud Bull, to publicise the colony. The Society contributed to a permanent exhibition of colonial products in London's Crystal Palace - all with the intention of promoting Tasmania abroad.

At the same time issues of local concern were pursued by the Society. It lobbied for the establishment of a meteorological observatory; a public time signal; an electric telegraph line across the island; the improvement of Queen's Domain; the preservation of trees on Mt Wellington; the extermination of the rabbit and codlin moth; the introduction of salmon; and the cessation of the pollution of the Derwent by tar from the gas works and refuse from the slaughterhouse. It was at meetings of the Society that, among other things, the telephone, the phonograph and the microphone were first demonstrated.

The Society's interest in the Tasmanian aborigines encompassed the recording of as much ethnological information about the race as possible, and lobbying the government to ptotect Bass Strait muttonbird rookeries, which provided a livelihood for the half-caste population of the Islands.

The Society remained keenly interested in the question of acclimatisation of species and establishing new industries and its endeavours could be truly described as creating world-wide interest. When, for example, at the suggestion of Edwin Pears (a former school master at New Town and Royal Society member, then a barrister in Istanbul), the British Consul at Ankara wrote to the Society in 1874 to suggest the acclimatisation of the Angora goat, the members' keen discussion, which was reported in Papers and Proceedings, generated further correspondence on the subject from Santa Barbara, USA.

The membership that supported these activities fluctuated considerably. In 1848 membership increased from 81 to 123; and by 1854 a high point of 330 was reached although only 240 were financial. As the effects of the economic depression of the 1850 s became widespread, the local membership declined as many people left Tasmania for the more prosperous colony of Victoria, and some Corresponding Members joined the scientific societies which were being established in other colonies. Finance became a major problem and the publication of Papers and Proceedings was suspended, as were purchases for the library.

The person who, through good management, personal generosity, and his ability to obtain aid for the Society, was able to liquidate the Society's debt was Dr James Agnew (the successor as Secretary to Dr Milligan) who remained a leader in the Society's affairs until the 1890s. His name, together with that of Morton Allport and Francis Abbott, constantly appeared as a sponsor of new members, in vigorously mounted membership drives by the Society. 


\section{PAPERS AND PUBLISHING}

After the last issue (in 1849) of the Tasmanian Society's Tasmanian Journal, the Royal Society's own transactions were published, providing the only vehicle within Australia for publishing scientific papers. Many writers became Corresponding Members for this opportunity to publish, and then became donors to the Museum because of their association with the Society.

At its meetings, members reported items of interest which ranged from remedies for blight in apple trees to the reproductive properties of Egyptian mummy wheat (grain from one ear of wheat yielded 872 ears according to Bishop Nixon). Similarly, the early papers were practical and designed to assist settlers in a new land: to improve current agricultural practices or suggest new industries. Such papers always stimulated the most vigorous discussion. Papers of a more scientific nature, for example new species of flora or fauna and geological discoveries, were welcomed because their publication enhanced the stature of the society. Gradually the Society became more discriminating about its publications: papers were only published if they contained original material and were not simply resumés of known knowledge; named specimens had to accompany any paper on new species, and papers had to be submitted to the Council in advance.

Baron von Mueller, a distinguished Corresponding Member, wrote of the "praiseworthy regularity and punctuality with which the Society issues its papers [which] affords the most favourable vehicle in Australia for the early recording of new observations". 1 Outstanding local contributors included the Reverend J.E. Tenison-Woods, W. Legrand, W.F. Petterd, and R.M. Johnston for their

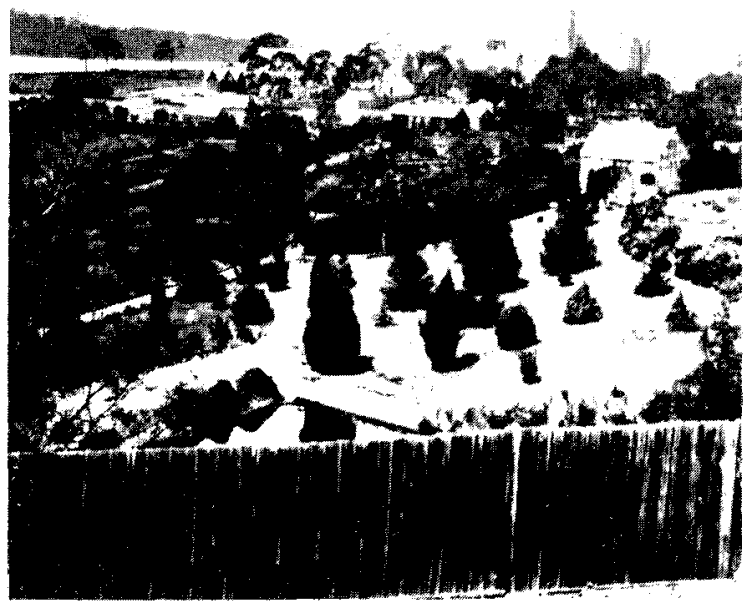

PLATE 2

The Royal Society's Gardens, Hobart, with Government House in the background. Charles Abbott, photographer, 1858. (W.L. Crowther Library, State Library of Tasmania, Hobart.) work on the marine, freshwater and fossil shells of the island. (Johnston, incidentally, was the most prolific contributor of papers to the Society in the nineteenth century.)

Morton Allport is one who exemplifies well the extent of the local, intercolonial and international scientific network. He joined the Royal Society in 1849, was a member of its Gardens Sub-Committee and a Vice-President from 1870 1878. In 1866 he was appointed one of the salmon commissioners. He was an organiser for the Great Exhibition in 1862, and a Commissioner for the Intercolonial Exhibition of Australia at Melbourne 1866-67. He was an agent for the ornithologist John Gould, and one of the earliest photographers in the colony. He was also responsible for the successful introduction of perch and tench into Tasmania. He corresponded with a number of scientific men in Europe, most notably with Dr Gunther of the British Museum, sending him specimens at his own expense. Allport received in return a great deal of valuable information which he passed on to the Society. A Fellow of the Linnaean and Zoological Societies and of the Royal Institute, he was also a Corresponding Member of the Anthropological Institute of Great Britain, a Life Member of the Entomological and Malacological Societies, a Foreign Member of the Royal Linnaean and Royal Botanical Societies of Belgium, and a Fellow of the Linnaean Society of New South Wales. His contribution to the Royal Society of Tasmania, until his early death at the age of 47 , was a distinguished one.

\section{THE LIBRARY}

Provision was made in the original rules of the Society for a library and, initially, a library of general literature, to which the public would have access, as it did to the Society's Gardens and Museum, was envisaged. When a separate public library was established in 1849 it was decided not to compete in establishing a general collection but that the Royal Society would concentrate on building a major scientific collection to which the public would have access.

From the first distribution of complimentary copies of the Papers and Proceedings in 1849, an international network of publications exchange developed which immeasurably enhanced the Library. By the 1870 s the Library was described by one scientific writer (and traveller) as "the best and most extensive collection of scientific works in the Australian colonies"; 11 and the Society was exchanging publications worldwide with universities, State and Federal government departments and independent organisations. When one considers factors such as distance, time, cost and risk of loss, the achievement is enormous. (The quality of the book and journal collection is perhaps the greatest single achievement of the 150-year history of the Society.)

\section{THE GARDENS}

In the minds of the public, however, in the early days, it was the Gardens and the Museum which provided a public face for the Society. It was, after all, for the administration of the Gardens that the Society had been set up. At the outset the fourteen acres of Colonial Gardens for which the Society received a $£ 400$ government grant, comprised mainly fruit trees and better known European plants and shrubs, with only a small collection of indigenous plantsand rarer European 
varieties. The value of belonging to the Society for many, however, was access to these Gardens (plus free plants and cuttings) and the right to take visitors there. But from the first year of its existence the Society began to move towards a position where it administered the Gardens in the interests of the public, its own members enjoying no special privileges. While the sale of plants provided a welcome income, the Society was anxious not to compete unfairly with the professional nurserymen of the town by the sale of popular plants at cheaper prices. From 1845, an intercolonial and international exchange system of plants and seeds was set up and there was an increasing emphasis on developing the indigenous, exotic, and acclimatised plant collections. Common fruits and vegetables were only cultivated to demonstrate some new or important characteristic of the plants, or application of their products.

Judging from the Society's reports, however, it valued the Gardens for their recreational and educational qualities and their beneficial effect on the community's health and morals, as much as for their botanical significance. Visitor numbers rose from 2287 in 1847 to 15710 in 1855 , the weekly performances of the band of the 99th Regiment contributing to the Gardens' popularity.

The administration and development of the Gardens remained the pre-eminent activity of the Society in some members' opinion. In its endeavours the Society was well served by the two superintendents of the early period: F.W. Newman until 1859 and then Francis Abbott. The latter managed - despite an increasingly inadequate grant - to raise plants for sale; conduct plant and seed exchanges with individuals and institutions worldwide; solicit and acknowledge donations; continue to extend the area of gardens under cultivation to 25 acres (approx. $10 \mathrm{ha}$ ) by 1877 , with in excess of 7000 varieties of plants (using a staff largely comprising inexperienced prison labour); and also cope with visitors who in that year (1877) numbered nearly 56000 .

\section{THE MUSEUM}

As with the Gardens, an increasing number of people visited the Society's Museum : 683 in 1853 compared with 5680 five years later. Thomas Roblin was appointed Curator in 1862 and this "faithful, zealous and efficient officer"12 laboured to build up the collection.

The government grant was spent on salaries, administration, rent and maintenance of the building but not on the collection itself. Even more than the partly self-supporting Gardens (with plant sales) and the library (with its publication exchanges) the Museum was dependent on donations, both from resident and Corresponding Members, local non-members and individuals and institutions beyond the colony. The exchange of duplicate specimens was the only other way the museum could build up its collection. (In return for one Tasmanian Tiger the Australian Museum in Sydney gave the Society 78 specimens of mammals, birds and reptiles so the system could be advantageous.)

From its earliest days the Society was keen to provide a permanent home for its growing collection. When visitor numbers dropped from over 6000 in 1859 to 427 the following year, the major reason was said to be the unattractive overcrowding of exhibits. The Council of the Society sought from the government a central site and a special grant for a building "becoming in architectural character and ample enough for the demands of a century or two". ${ }^{13}$ Joseph Milligan, the first Secretary of the Society, was outspoken where others might have compromised and finally the government gave the present Museum site. Henry Hunter's architectural design was chosen in a public competition and the lowest building tender (offered by Messrs Seabrook and Son) was accepted. The foundation stone was laid in August 1861 and the building was completed the following year - an art exhibition being held to provide the fittings for the Museum. Individual members assisted in organising the new Museum. Charles Gould, Government geologist, arranged the geological section, adding to it a collection he had received from Sir Roderick Murchison in England.

Visitor numbers did not really climb until 1877 when the Museum was opened on Sundays. Within a year attendance on Sundays during one month exceeded that on weekdays for the same period and in 1878 almost half of the 33466 visitors came on Sundays. There was little overt protest at Sunday opening although at least one person, James "Philosopher" Smith, declined honorary membership of the Society (offered in recognition of his contribution to the mining industry) because the Society opened its Museum on Sundays.

During 1885, there was a marked increase in donations to the Museum, probably due to the activities of the new curator Alexander Morton. Throughout the year the Council made strong representations to the government for increased finance for the Museum, and for extensions to be built. But although the Society worked within a network of influence in many things, it could not persuade the government to endow the Museum and the Gardens more adequately.

\section{CONCLUSION}

While making rules and regulation for managing the Gardens, the Council found they had not power to enforce them because the grounds were not vested in the Society. It had originally been allowed to take up the land but had no title to it. Secondly, the Society wanted to secure the small area adjacent to the Museum for extensions and was concerned that it might be developed commercially. The Council wrote

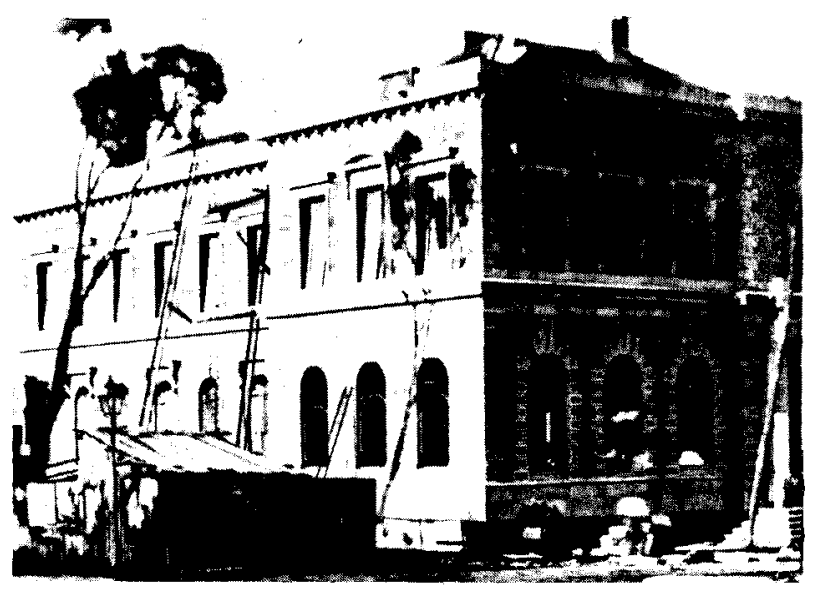

PLATE 3

The Royal Society's new Museum, corner of Argyle and Macquarie Streets, Hobart. Samuel Clifford, photographer, 1862. W.L. Crowther Library, State Library of Tasmania, Hobart.) 
to the Premier to request the vesting of the site of the Museum and Gardens in the Trustees of the Royal Society. This had been mooted when the Museum was built, and favourably considered by the Government, but not acted upon.

After some consideration of the need for regular and permanent financial support, legal ownership, and the desirability of giving the two institutions a "national" character, the Council drew up a draft proposal for the government to endow and incorporate the Museum and Gardens. It was to be totally accepted by Parliament or the Bill would be withdrawn. The draft was based on the New South Wales Museum Act.

It was accepted, and in 1886, a new phase of the Society's existence began. With the transfer of the Gardens and the Museum, the Society's role in the community was less apparent. But its scientific contacts with other countries were maintained and strengthened through its Papers and Proceedings, and its role as a scientific society, disseminating original scientific data, increased under the guidance of Dr Agnew and Alexander Morton, who were to serve the Society for many more years.

The year 1886 is an appropriate one at which to finish, for it not only signified the end of an era in Tasmania, but the beginning of another for Australian science. Professor A. Liversidge, President of the Royal Society of New South Wales, established (in that year) a federal association of the thirty-eight scientific bodies, which existed in Australasia: the Australasian Association for the Advancement of Science - the first national scientific body in Australia. Its first President, H.C.C. Russell, said: "This association stands as a protest against the short-sighted and utilitarian policy of those who would cultivate only what they characteristically call the bread and butter sciences. Our purpose is the advancement of all the sciences." 14 Freed of two responsibilities which had been the source of much financial and managerial worry, the Royal Society of Tasmania was in a stronger position to respond to this challenge in the following years.

\section{REFERENCES}

1. The material in this article has been taken from the author's unpublished BA (Hons) thesis: For ... the Advancement of Science": the Royal Society of Tasmania, 1843-1885. University of Tasmania, Hobart, 1972.

2. Held in the Archives of the Royal Society of Tasmania at the University of Tasmania.

3. Minutes of the Council [of the VDL Horticultural and Botanical Society] 14 actober 1843. Held in the Archives of the Roval Society of Tasmania at the University of Tasmania.

4. Rules of the ... Society ... October, 1843, Hobart Town, 1843, Rule VIII, p.7.

5. R.C. Gunn to J.D. Hooker, 29 March 1845. Letter 191. In Burns, T.E. \& Skemp, J.R.: VAN DIEMEN'S LAND CORRESPONDENTS 1827-49. Launceston, 1961: 111.

6. R C Gunn, unaddressed note, probably to J .E. Bicheno, 26 November 1844. In Burns, T.E. and Skemp: VAN DIEMEN'S LAND CORRESPONDENTS 1827-49. Launceston, 1961: 112.

7. Letter from Eardley-Wilmot to the Society, 30 September 1845 , appended to the Minutes of the Council, 2 Octobèr 1845.

8. Maiden, J.H. "... a history of the Royal Society of NSW .... J. R. Soc. NSW 52 (1918): 360.

9. Letter to Admiral Beaufort, 5 February 1849. In Denison, W.T.: VARIETIES OF VICE-REGAL LIFE, vol. 1. London, 1870: 107.

10. Pap. Proc. \& Rep. R. Soc. Tasm. 1875, p.163.

11. Reverend J.E. Tenison-Woods at the Monthly meeting of the Society, 8 August 1876. In Pap. Proc. R. Soc. Tasm. (1876): 67.

12. Rep. R. Soc. Tasm. (1883): 16.

13. Rep. R. Soc. Tasm. (1856): 17.

14. Report of the first meeting of the Australasian Association for the Advancement of Science, vol I, (1888): 14.

(accepted 3 August 1993) 